\title{
ASSESSMENT OF HEAVY METAL FOCUSING ON CADMIUM, COPPER AND LEAD UPTAKE BY CROPS IN GREATER BANGKOK METROPOLITAN REGION, THAILAND
}

\author{
Thach Huynh Thi Thu Trang ${ }^{1}$, Lai Phuoc Son ${ }^{2}$
}

Abstract - The objective of this study is to assess heavy metals, copper, cadmium and lead, uptake by food crops and vegetables grown in the greater Bangkok Metropolitan Region in Thailand. The three heavy metals were detected in three types of vegetables cultivated in three provinces Pathum Thani, Ayutthaya, and Nonthaburi representing Greater Bangkok Metropolitan Region (GBMR). An Inductively Coupled Plasma method was used to estimate and evaluate the levels of these metals' concentration in the vegetables, soil, water, manure, and chemical fertilizer. The physical and chemical characterizations of which were conducted to compare the heavy metals concentrations with similar characteristics. Heavy metals concentrations were compared both in wet and dry season. Moreover, the edible and non-edible parts of the vegetables were also considered for the comparative study and found a significant difference in copper $(\mathrm{Cu})$ concentrations in morning glory. The concentrations of $\mathrm{Cu}$ were found in edible and non-edible parts were 0.38 and $1.10 \mathrm{ug} / \mathrm{g}$ respectively. To account the flow of heavy metals concentration in

\footnotetext{
${ }^{1,2}$ Biotechnology and Environment Center, School of Agriculture and Aquaculture, Tra Vinh University.

Email: thtttrang@tvu.edu.vn

Received date: $14^{\text {th }}$ October 2020; Revised date: $30^{\text {th }}$ November 2020; Accepted date: $25^{\text {th }}$ December 2020
}

certain location, a mass balance analysis was conducted for the three different provinces, and found that about $18 \mathrm{mg}$ of $\mathrm{Cu}$ accumulated in all three provinces. The cadmium $(\mathrm{Cd})$ and lead $(\mathrm{Pb})$ levels were found to be insignificant. The contributions of the vegetables to the daily intake of the heavy metals from the vegetables were determined.

Keywords: heavy metal, cadmium uptake, food crops and vegetables, Bangkok Metropolitan Region.

\section{INTRODUCTION}

In the recommended daily diet vegetables are necessary due to the vitamins, cellulose and water it provides. However, vegetables in many areas are contaminated by pollutants from the soil or irrigation water. So nowadays, sourcing clean vegetables is becoming a more public concern [1]. Vegetables have been found to contain such pollutants as pesticides, heavy metals, and pathogenic microorganism [2]. In the environment, heavy metals occur naturally as components of soil and water and can be transferred through local plants and animals that are used for food [2], [3]. These heavy metals can lead to negative effects on the quality of cultivated plants and animals and later on the health of 
consumers [2], [3]. Many heavy metals are essential for biological growth and do not lose their mass or properties during transportation [2], [4], they can adversely affect all living organisms if they are present in excessive amount. Most heavy metals are highly toxic to ecosystems at low concentrations [5].

Contamination of heavy metal in vegetables is a serious problem because they can accumulate in the bodies of the consumer. This can cause damage to the nervous system, negatively affect the skin, hair and can cause cancer. Copper $(\mathrm{Cu})$, lead $(\mathrm{Pb})$, mercury $(\mathrm{Hg})$ and others can cause impaired vision, brain damage and paralysis, and cadmium $(\mathrm{Cd})$ can cause ouch-ouch (Itai itai) disease especially in children and pregnant women [6]. Several studies have indicated that vegetables cultivated in urban area or nearby industrial zones have been contaminated by heavy metal concentrations more so than areas which are not near these areas [7].

Furthermore, industrial activities, smelting, using fertilizers, pesticides, organic manures are leading to further soil contamination. Concentrations of $\mathrm{Pb}$, $\mathrm{Zn}, \mathrm{Cr}$, and $\mathrm{Mn}$ were found particularly in leafy vegetables. The dominant pathway for most trace elements to roots was from the soil, while trace elements in the leaves appeared to originate mostly from the atmosphere. High accumulation due to atmospheric deposition was found for $\mathrm{Pb}$, $\mathrm{Cd}$, especially in leafy vegetables [2]. Root vegetables were found to accumulate $\mathrm{Cd}$ more so than other trace elements.

Therefore, the objective is to determine $\mathrm{Cu}, \mathrm{Pb}$, and $\mathrm{Cd}$ in selected vegetables (morning glory, lettuce, and Chinese radish) in the GMBR, and to assess the heavy metal concentrations in the soil, water, and fertilizer during both the wet and dry seasons.

\section{STUDY OVERVIEW}

According to Le Thanh Tam and Nguyen Minh Khang [8], University of Agriculture and Forestry of Ho Chi Minh City, through data collection combined with field surveys and experiments have shown that heavy metal content, especially lead $(\mathrm{Pb})$, affects the growth of green vegetables. Lead accumulation in plants has a positive correlation with the amount of lead in the soil.

Nguyen Ngan Ha et al. [9] assessed the current status of soil environment and accumulation of some nitrates in vegetable farms in Yen Nghia ward, Dong Da district, Hanoi City in 2016, Cu concentration accumulated in the soil was slightly low, while Lead $(\mathrm{Pb})$ of all soil samples tested was smaller than the pollution limit, but according to the rating scale of Obukhow AL, the flexible Lead $(\mathrm{Pb})$ content is also relatively high. Total Cadmium concentration and flexibility in most soil sample studies is assessed to be relatively high but is still within the limits [8]. But $\mathrm{Cu}, \mathrm{Pb}$ and $\mathrm{Cd}$ concentration in lettuce and cruciferous vegetables when compared with the FAO/WHO 1993 standard, were contaminated with $\mathrm{Cd}$, and when compared to the 99/2008/QD-BNN standard, the vegetables were contaminated with $\mathrm{Pb}$ at high levels.

The result showed that currently in Dong Anh District, Hanoi, Vietnam, the majority of soil, water and vegetable samples are contaminated with heavy metals. The cause of heavy metal contamination 
in vegetables with $\mathrm{Pb}$ and $\mathrm{Cd}$ is due to water contamination, perhaps due to farmers using a lot of phosphate fertilizers with high levels of [10].

The samples gathered were from morning glory, lettuce and Chinese radish to ensure the health and safety of consumers of these three vegetables. After analyzing, if the concentration of heavy metals exceeds the recommended level, it is suggested that people not use vegetables grown in that area, and to discontinue growing food crops there. In the future, measures should be proposed to farmers to guarantee that vegetables are grown on clean soil, use clean water for irrigation, and use organic fertilizers to limit heavy metal contamination.

\section{METHODOLOGY}

The Inductively Coupled Plasma (ICP) method is used in this study to measure the processed samples, it is able to detect trace levels of heavy metals, and is more accurate that other methods such as spectroscopy absorption, and atomic emission spectroscopy [11].

\section{A. Characterization of vegetables, water,} soil, manure and chemical fertilizer

The study was conducted in two types of food markets, supermarket (Big C, Lotus, and Big C Quality Product) and wholesale market (Thala Thai and Simmumuong) as well as samples from three different provinces (Nonthaburi, Pathum Thani, and Ayutthaya). The three different types of vegetables around three kilograms of each type was collected from different vendors in different markets and vegetables, soil, water, manure and chemical fertilizer were also collected from the above mentioned provinces.

After collecting the samples, the samples were processed and frozen at $4-6^{\circ} \mathrm{C}$. The physical and chemical properties of vegetables, soil, water, manure and chemical fertilizers were analyzed.

\section{B. Heavy metal concentrations in vegeta-} bles, soil, manure and chemical fertilizer

The determination of heavy metals concentration was carried out to assess the levels of three heavy metals $(\mathrm{Cu}, \mathrm{Cd}$ and $\mathrm{Pb}$ ) which have been known to have significant effects on plant growth and accumulation. To compare the concentrations in the vegetables, soil, water, manure, and chemical fertilizer, across the wet and dry seasons. For further investigation, the edible and non-edible parts of the vegetables were also analysed to assess the potential effects on consumers.

The overall experiment was divided into two parts. In part 1 , the vegetable samples were obtained from the farms, andin part 2 the vegetables were taken from local markets and supermarkets. The study areas represented the Greater Bangkok Metropolitan Region (GBMR) in the previously mentioned provinces at which vegetables were taken from those farms in both the wet and dry seasons. Likewise, similar vegetables from the two market types were also sampled, and the layout of the plan is presented in Figure 1.

Sampling location: This is a map of Thailand showing the three provinces from which vegetable, soil, water and fertilizer samples were taken. 


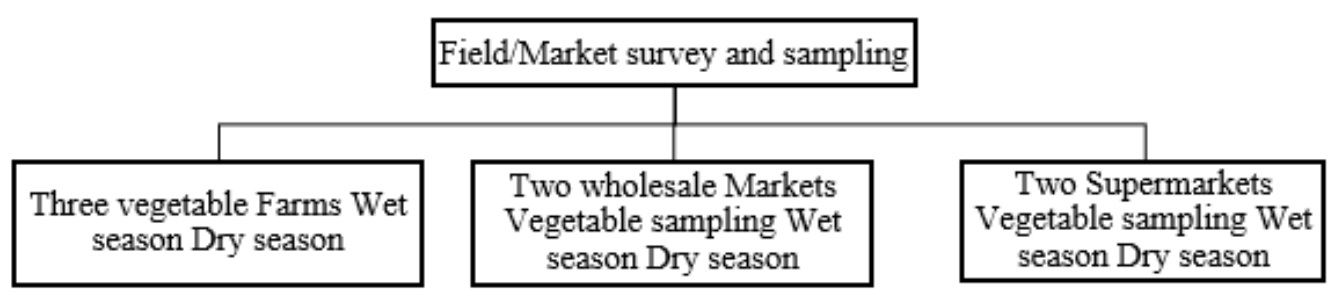

Fig. 1: Overall Framework

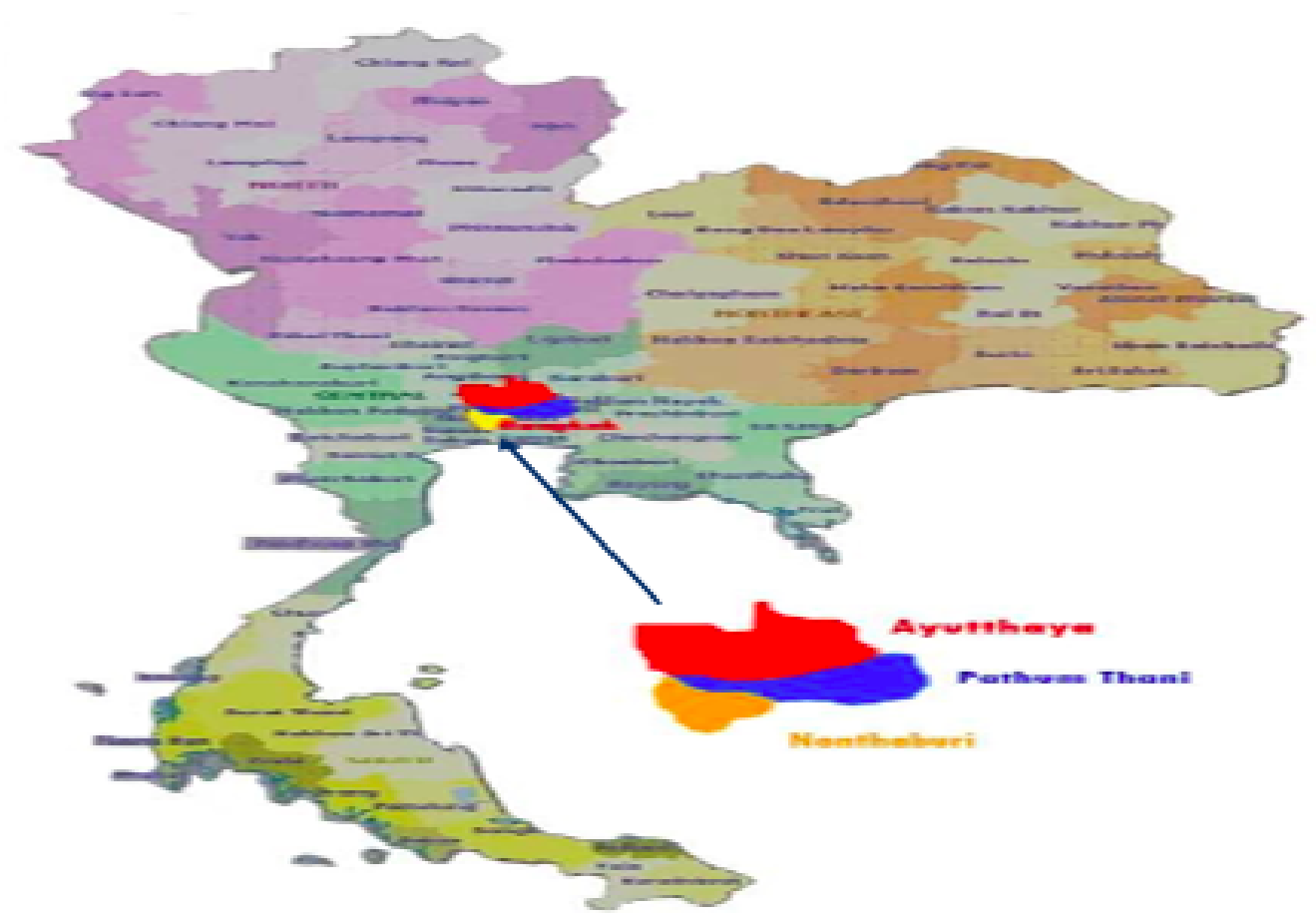

Fig. 2: Sampling Locations of Vegetables from GBMR

Schedule and number of samples: At the farm 170 samples were taken, 86 of them were sampled in the wet season and the remaining 84 were collected in the dry season. During each season 18 vegetable samples, 36 soil samples, and 7 water samples were collected. The rest were attributed to chemical fertilizer and manure samples. At the market 23 samples of vegetables were obtained. All the samples were prepared and pretreated before conducting the chemical analysis. The concentrations of the three heavy metals $(\mathrm{Cu}, \mathrm{Cd}, \mathrm{Pb})$ were measured from those samples.

C. Analysis of plant samples

Determination of Moisture Content (MC) 
To determine the moisture content of the vegetables, the vegetables were first mixed and were subsampled to smaller sizes. After sampling, the vegetables were cleaned before being cut into small pieces. Then the samples were weighed and put in an oven at $100^{\circ} \mathrm{C}$ for 12 hours. After drying the weights of the vegetables were taken, and the moisture content of the vegetables was determined by the following equation: $M C=(W b-W a) / W b \times 100 \%$.

Where, $\mathrm{Wb}=$ Weight of vegetables before drying $(\mathrm{g}) \mathrm{Wa}=$ Weight of vegetables after drying (g) MC = Moisture Content

Chemical Fertilizer, Soil and Manure Analysis

The heavy metal concentration in fertilizer is usually higher than in the plant but for the samples the concentration is not high so only ICP-OES was used. The procedure followed a stepwise analysis of chemical fertilizer in this study.

Soil samples taken from the vegetable plots at depths from 0 to $15 \mathrm{~cm}$ were sampled and kept in the refrigerator at a temperature of between 4 and $60 \mathrm{C}$, then digested with a mixture of solutions (HNO3: HCL) and the solution was determined by ICP-OES.

Manure samples obtained from the farms were digested with a mixture of solutions (HNO3: HCL) and the solution was determined by ICP-OES.

\section{Vegetable soil characterization:}

All soil samples collected from those vegetable plots from the farm fields were characterized for their $\mathrm{pH}$ (in 1:1 water) and organic matter (OM) content using the Walkley and Black method (1947). The soil texture (sand, silt, and clay fraction), was determined using the hydrometer method.

\section{Data analysis}

All collected data was processed by Microsoft Excel 2016 software to determine the mean value for each research result.

\section{RESULTS AND DISCUSSION}

\section{A. Wet season}

\section{Heavy Metal Concentration in Veg- etables}

The concentrations of the heavy metals in vegetables were measured using ICPOES methods. The results are shown in Table 1 and 2, and present the heavy metal concentration in edible and nonedible parts of the vegetables respectively. The heavy metal concentrations in nonedible plant parts was found higher than that of edible parts, although the these values in edible parts of lettuce were more than the Codex value which indicates safe consumption.

Heavy Metal Concentration in Soil, Fertilizer, and Water in the Wet Season

The concentrations of heavy metals in soil, fertilizer, and water were measured using ICP-OES methods. The results are shown in Table 3.

Copper concentrations in the chemical fertilizer were found higher in Pathum Thani and Ayutthaya compared to cadmium and lead concentrations (Table 3). Whereas chemical fertilizer NPK 16-1616 (used for lettuce) and NPK 16-16-16 (Chinese radish) had higher concentrations of these heavy metals in Nonthaburi. Similarly, manure also was contaminated with heavy metals and the concentrations were higher than in Ayutthaya.

Based on soil analysis, all land for vegetable of the three provinces showed quite 
Table 1: Heavy metals concentration in vegetables (edible parts)

\begin{tabular}{|l|c|c|c|c|c|c|c|c|c|}
\hline \multicolumn{10}{|c|}{ Edible Part (ug/g ww) } \\
\hline Parts of Vegetable & \multicolumn{1}{|c|}{ Farm Pathum Thani } & Farm Nonthaburi & \multicolumn{3}{|c|}{ Farm Ayutthaya } \\
\hline Heavy metal & $\mathrm{Cu}$ & $\mathrm{Cd}$ & $\mathrm{Pb}$ & $\mathrm{Cu}$ & $\mathrm{Cd}$ & $\mathrm{Pb}$ & $\mathrm{Cu}$ & $\mathrm{Cd}$ & $\mathrm{Pb}$ \\
\hline Morning Glory (leaf \& stem) & 0.38 & 0.01 & 0.02 & 0.63 & 0.01 & 0.03 & 0.57 & 0.02 & 0.04 \\
\hline Lettuce (leaf) & 0.36 & 0.02 & 0.04 & 0.33 & 0.01 & 0.01 & $\mathrm{Nd}$ & nd & nd \\
\hline Chinese Radish (root) & nd & nd & nd & 0.19 & 0.00 & 0.02 & $\mathrm{Nd}$ & nd & nd \\
\hline Codex value (ug/g) & 2 & 0.2 & 0.3 & 2 & 0.2 & 0.3 & 2 & 0.2 & 0.3 \\
\hline
\end{tabular}

(Note: nd: not detectable)

Table 2: Heavy metals concentration in vegetables (Non-edible parts)

\begin{tabular}{|l|c|c|c|c|c|c|c|c|c|c|}
\hline \multicolumn{10}{|c|}{ Non- edible Part (ug/g ww) } \\
\hline Name of samples & \multicolumn{1}{|c|}{ Farm Pathum Thani } & \multicolumn{1}{|c|}{ Farm Nonthaburi } & \multicolumn{3}{|c|}{ Farm Ayudthaya } \\
\hline Name of heavy metal & $\mathrm{Cu}$ & $\mathrm{Cd}$ & $\mathrm{Pb}$ & $\mathrm{Cu}$ & $\mathrm{Cd}$ & $\mathrm{Pb}$ & $\mathrm{Cu}$ & $\mathrm{Cd}$ & $\mathrm{Pb}$ \\
\hline Morning Glory & 1.10 & 0.02 & 0.12 & 1.64 & 0.02 & 0.15 & 1.45 & 0.03 & 0.45 \\
\hline Lettuce & 0.35 & 0.01 & 0.01 & 0.25 & 0.01 & 0.02 & $\mathrm{Nd}$ & $\mathrm{Nd}$ & nd \\
\hline Chinese Radish & $\mathrm{Nd}$ & nd & nd & 0.16 & 0.00 & 0.01 & $\mathrm{Nd}$ & $\mathrm{Nd}$ & nd \\
\hline
\end{tabular}

(Note: $n d:$ not detectable)

Table 3: Heavy metal concentration in soil, fertilizer, and water in wet season

\begin{tabular}{|c|c|c|c|c|c|c|c|c|c|c|}
\hline $\begin{array}{l}\text { Samples } \\
\text { analysis }\end{array}$ & $\begin{array}{c}\text { Types of Ve. \& } \\
\text { Fertilizer and } \\
\text { heavy metal }\end{array}$ & Farm & $\begin{array}{l}\text { athun } \\
(u g / g)\end{array}$ & Thani & $\begin{array}{l}\text { Farm I } \\
\text { ug/g) }\end{array}$ & ontha & buri & Farm & $\begin{array}{l}\text { Ayut } \\
\text { ag/g) }\end{array}$ & laya \\
\hline \multirow{4}{*}{ Soil } & Heavy metal & $\mathrm{Cu}$ & $\mathrm{Cd}$ & $\mathrm{Pb}$ & $\mathrm{Cu}$ & $\mathrm{Cd}$ & $\mathrm{Pb}$ & $\mathrm{Cu}$ & $\mathrm{Cd}$ & $\mathrm{Pb}$ \\
\hline & MG & 33.49 & 0.01 & 18.65 & 25.23 & $\begin{array}{c}0.0 \\
0\end{array}$ & $\begin{array}{c}15.2 \\
2\end{array}$ & 24.71 & $\begin{array}{c}0.0 \\
0\end{array}$ & $\begin{array}{c}23.1 \\
8\end{array}$ \\
\hline & L & 29.41 & 0.01 & 16.69 & 15.93 & $\begin{array}{c}0.0 \\
0\end{array}$ & $\begin{array}{c}13.8 \\
4\end{array}$ & na & na & na \\
\hline & $\mathrm{CR}$ & na & na & na & 18.41 & $\begin{array}{c}0.0 \\
1\end{array}$ & $\begin{array}{c}15.5 \\
8\end{array}$ & na & na & na \\
\hline \multirow{4}{*}{ Chemical Fertilizer } & $\begin{array}{c}\text { NPK 16-16-16 } \\
\text { (MG) }\end{array}$ & 0.26 & 0.03 & 1.72 & na & $\mathrm{Na}$ & na & 0.20 & $\begin{array}{c}0.1 \\
0\end{array}$ & 1.41 \\
\hline & NPK 16-16-16 (L) & na & na & na & 0.44 & $\mathrm{Nd}$ & 2.76 & na & na & na \\
\hline & $\begin{array}{c}\text { NPK 16-16-16 } \\
\text { (CR) }\end{array}$ & na & na & na & 0.51 & $\begin{array}{c}0.2 \\
2\end{array}$ & 3.00 & na & na & na \\
\hline & NPK $15-0-0$ (CR) & na & na & na & 0.01 & $\begin{array}{c}0.0 \\
1\end{array}$ & nd & na & na & na \\
\hline \multirow{3}{*}{ Water $(\mu g / L)$} & MG & 4.31 & 0.52 & 9.01 & 1.67 & $\mathrm{Nd}$ & 0.81 & nd & nd & 2.47 \\
\hline & L. & nd & nd & 5.33 & 1.74 & $\begin{array}{c}0.0 \\
1\end{array}$ & 9.22 & 4.31 & nd & 2.24 \\
\hline & $\mathrm{CR}$. & na & na & na & nd & $\mathrm{Nd}$ & nd & na & na & na \\
\hline \multirow[t]{2}{*}{ Manure } & MG & 24.64 & 0.60 & 5.04 & na & $\mathrm{Na}$ & na & $\begin{array}{c}126.1 \\
6\end{array}$ & $\begin{array}{c}0.8 \\
0\end{array}$ & 8.17 \\
\hline & $\mathrm{L}$. & 203.13 & 0.75 & 32.19 & na & $\mathrm{Na}$ & na & na & na & na \\
\hline
\end{tabular}

(Note:MG=Morning Glory, $L=$ Lettuce, $C R=$ Chinese Radish, na: not available; $n d$ : not detectable) 
uncontaminated and has $\mathrm{Cu}$ and $\mathrm{Pb}$ similar to other typical agricultural soils elsewhere in Thailand. However, one batch of manure used by farmers at Pathum Thani was quite high in $\mathrm{Cu}$ and $\mathrm{Pb}$ with a value around $110 \mu \mathrm{g} / \mathrm{g}$ (Table 3) and 7.5110 $\mu \mathrm{g} / \mathrm{g}$ when compared with the other samples available. Since manure is used quite often to improve soil structure and water holding capacity in vegetable plots, this would represent one source of heavy metals added into the soil unintentionally and lead to heavy metal accumulation in the soil. To avoid heavy metal contamination in soil, manure used in the farm should be checked from time to time to control the quality especially when they will be applied for growing vegetables.

From the experiment it was found that some chemical fertilizers as shown in Table 4 were contaminated with heavy metals, and were highest in Nonthaburi Province. But these concentrations were different and dependant on the brand fertilizer.

Research results in Table 4 showed that, soil samples growing morning glory at the farm in Ayutthaya had the highest $\mathrm{Cu}, \mathrm{Cd}$, and $\mathrm{Pb}$ concentrations(24.01, 0.22 , and $19.85 \mathrm{ug} / \mathrm{g}$ respectively). But the soil samples growing lettuce and Chinese radish did not detect any contamination. The sample of soil growing lettuce and Chinese radish on farms in Nonthaburi Province had higher contamination than the two other provinces.

The water samples for morning glory at a farm in Ayutthaya province had the highest $\mathrm{Cu}$ concentration, accounting for $3.63 \mathrm{ug} / \mathrm{L}, \mathrm{Pb}$ and $\mathrm{Cd}$ were not detected. The $\mathrm{Cu}$ concentration in the lettuce water sample at the Ayutthaya farm was 3.96 $\mathrm{ug} / \mathrm{L}$, and was higher than on Pathum Thani farm which was $3.51 \mathrm{ug} / \mathrm{L}$, although this difference was deemed not significant. The $\mathrm{Cu}$ concentration in water samples for Chinese radish in Nonthaburi was detected at $3.37 \mathrm{ug} / \mathrm{L}$, while the other two provinces none was detected. Whereas $\mathrm{Pb}$ and $\mathrm{Cd}$ in water samples were not detected in any of the three provinces.

\section{B. Dry season}

The contents are presented in Tables 5, 6 and 7.

\section{Comparison of Heavy Metal Concen-} trations in Vegetables, Water, Fertilizer, Manure, and Soil Samples

\section{Wet season in the farm}

As seen from Figure 3, the $\mathrm{Cu}$ concentrations found in the morning glory samples were highest in Nonthaburi, and lowest in Pathum Thani. Nonthaburi Province is located nearby highways and busier roads which is one of the major sources of heavy metal pollution, according to Abideen Adeyinka Adekanmi et al. [7] the heavy metals might be transported from soil to ground water or taken up by plants, such as agricultural crops. It is well known that high industrial and traffic activities contribute to high levels of heavy metals in the environment. Concentrations of $\mathrm{Cd}(0.01 \mathrm{ug} / \mathrm{gWW})$ in two provinces were similar except for samples from Ayutthaya $(0.02 \mathrm{ug} / \mathrm{gWW})$. Although the Pb concentration in Ayutthaya was found higher than the other two provinces. 
Table 4: Concentration of heavy metal in soil, chemical fertilizer, and water, in three provinces in the dry season

\begin{tabular}{|c|c|c|c|c|c|c|c|c|c|c|}
\hline \multirow[t]{2}{*}{ Samples } & \multirow[t]{2}{*}{$\begin{array}{l}\text { Samples } \\
\text { analysis }\end{array}$} & \multicolumn{3}{|c|}{$\begin{array}{c}\text { Farm Pathum Thani } \\
(u g / g)\end{array}$} & \multicolumn{3}{|c|}{$\begin{array}{c}\text { Farm Nonthaburi } \\
(\mathbf{u g} / \mathrm{g})\end{array}$} & \multicolumn{3}{|c|}{$\begin{array}{c}\text { Farm Ayutthaya } \\
(\mathrm{ug} / \mathrm{g})\end{array}$} \\
\hline & & $\mathrm{Cu}$ & $\mathrm{Cd}$ & $\mathrm{Pb}$ & $\mathrm{Cu}$ & $\mathrm{Cd}$ & $\mathrm{Pb}$ & $\mathrm{Cu}$ & $\mathrm{Cd}$ & $\mathrm{Pb}$ \\
\hline \multirow{3}{*}{ Soil } & MG & 21.59 & 0.16 & 10.22 & 18.7 & 0.09 & 17.91 & $\begin{array}{c}24.0 \\
1\end{array}$ & 0.22 & 19.85 \\
\hline & L. & 22.46 & 0.3 & 12.84 & 6.22 & 0.08 & 6.11 & na & na & na \\
\hline & $\mathrm{CR}$. & na & na & na & 20.97 & 0.28 & 11.45 & na & na & na \\
\hline \multirow{5}{*}{ Chemical fertilizers } & NPK 21-0-0 & na & na & na & 27.98 & 0.21 & 0.54 & na & na & na \\
\hline & NPK 25-7-7 & na & na & na & 13.24 & 0.04 & 0.72 & na & na & na \\
\hline & NPK 9-24-4 & na & na & na & 6.61 & 0.17 & 4.01 & na & na & na \\
\hline & NPK $21-0-0$ & 5.48 & 0.11 & 0.07 & na & na & na & na & na & na \\
\hline & NPK 25-7-7 & 5.73 & 0.08 & 0.02 & na & na & na & na & na & na \\
\hline \multirow{3}{*}{ Water $(\mathrm{ug} / \mathrm{L})$} & MG & 2.12 & na & na & 3.29 & nd & nd & 3.63 & nd & nd \\
\hline & $\mathrm{L}$. & 3.51 & na & na & 3.96 & na & $\mathrm{na}$ & na & na & na \\
\hline & CR. & na & na & na & 3.37 & na & na & na & na & na \\
\hline
\end{tabular}

(Note: na: not available $M G=$ Morning Glory, $L=$ Lettuce, $C R=$ Chinese Radish)

Table 5: Concentration of heavy metal in edible parts of vegetable in three provinces

\begin{tabular}{|l|c|c|c|c|c|c|c|c|c|}
\hline \multicolumn{10}{|c|}{ Edible Part (ug/g ww) } \\
\hline \multirow{2}{*}{$\begin{array}{l}\text { Parts of vegetables \& } \\
\text { Codex value }\end{array}$} & \multicolumn{2}{|c|}{ Farm Pathum Thani } & \multicolumn{3}{c|}{ Farm Nonthaburi } & \multicolumn{3}{|c|}{ Farm Ayutthaya } \\
\cline { 2 - 12 } & $\mathrm{Cu}$ & $\mathrm{Cd}$ & $\mathrm{Pb}$ & $\mathrm{Cu}$ & $\mathrm{Cd}$ & $\mathrm{Pb}$ & $\mathrm{Cu}$ & $\mathrm{Cd}$ & $\mathrm{Pb}$ \\
\hline MG (leaf \& stem) & 0.16 & 0.01 & 0.01 & 1.48 & 0.01 & 0.04 & 0.5 & 0.01 & 0.03 \\
\hline Lettuce (leaf) & 0.16 & 0.01 & 0.01 & 0.23 & 0.01 & 0.02 & na & na & na \\
\hline CR (root) & na & na & na & 0.18 & nd & nd & na & na & na \\
\hline Codex value & 2.0 & 0.2 & 0.3 & 2.0 & 0.2 & 0.3 & 2.0 & 0.2 & 0.3 \\
\hline
\end{tabular}

(Note: na: not available $M G=$ Morning Glory, $L=$ Lettuce, $C R=$ Chinese Radish)

Table 6: Concentration of heavy metals in vegetables in non-edible parts in three provinces (dry season)

\begin{tabular}{|l|c|c|c|c|c|c|c|c|c|c|}
\hline \multicolumn{10}{|c|}{ Non- Edible Part -dry season (ug/g WW) } \\
\hline Parts of vegetables & \multicolumn{4}{|c|}{ Farm Pathum Thani } & \multicolumn{2}{c|}{ Farm Nonthaburi } & \multicolumn{3}{c|}{ Farm Ayutthaya } \\
\hline & $\mathrm{Cu}$ & $\mathrm{Cd}$ & $\mathrm{Pb}$ & $\mathrm{Cu}$ & $\mathrm{Cd}$ & $\mathrm{Pb}$ & $\mathrm{Cu}$ & $\mathrm{Cd}$ & $\mathrm{Pb}$ \\
\hline MG & 0.38 & 0.01 & 0.04 & 4.28 & 0.03 & 0.06 & 1.20 & 0.01 & 0.17 \\
\hline Lettuce & 0.28 & 0.01 & 0.01 & 0.23 & 0.001 & 0.01 & na & na & na \\
\hline CR & na & na & na & 0.17 & 0.00 & 0.02 & na & na & na \\
\hline
\end{tabular}

(Note: na: not available $M G=$ Morning Glory, $L=$ Lettuce, $C R=$ Chinese Radish) 
Table 7. Concentration of heavy metal in edible parts and non-edible parts in Market and Supermarket in dry season.

\begin{tabular}{|c|c|c|c|c|c|c|c|}
\hline \multirow[t]{2}{*}{ Place take sample } & \multirow[b]{2}{*}{$\begin{array}{c}\text { Part of } \\
\text { vegetable }\end{array}$} & \multicolumn{3}{|c|}{ Edible part (ug/gww) } & \multicolumn{3}{|c|}{ Non-edible part (ug/g ww) } \\
\hline & & $\mathrm{Cu}$ & $\mathbf{C d}$ & $\mathbf{P b}$ & $\mathbf{C u}$ & Cd & $\mathbf{P b}$ \\
\hline \multirow{3}{*}{ Thailadthai } & MG & 0.44 & 0.01 & 0.01 & 0.71 & 0.01 & 0.06 \\
\hline & L. & 0.26 & 0.01 & $\mathrm{Nd}$ & 0.24 & 0.01 & 0.00 \\
\hline & CR. & 0.11 & 0.00 & 0.00 & 0.19 & 0.00 & nd \\
\hline \multirow{3}{*}{ Simummuong } & MG & 0.97 & 0.01 & 0.04 & 1.81 & 0.02 & 0.09 \\
\hline & L. & 0.27 & 0.01 & 0.00 & 0.32 & 0.01 & 0.00 \\
\hline & CR. & 0.08 & 0.00 & 0.00 & 0.18 & 0.01 & 0.02 \\
\hline \multirow{3}{*}{ Lotus } & MG & 0.52 & 0.02 & 0.04 & 0.97 & 0.02 & 0.24 \\
\hline & L. & 0.42 & 0.01 & 0.02 & 0.3 & 0.01 & 0.01 \\
\hline & $\mathrm{CR}$. & 0.11 & 0.00 & 0.00 & 0.18 & 0.00 & 0.02 \\
\hline \multirow{3}{*}{ Big C QL } & MG & 0.71 & 0.00 & 0.01 & 1.28 & 0.01 & 0.03 \\
\hline & $\mathrm{L}$. & 0.33 & 0.01 & 0.01 & 0.31 & 0.01 & 0.00 \\
\hline & $\mathrm{CR}$. & 0.06 & 0.00 & 0.01 & 0.1 & 0.01 & 0.03 \\
\hline \multirow{3}{*}{ Big C } & MG & 0.01 & 0.01 & 0.04 & 0.01 & 0.01 & 0.21 \\
\hline & L. & 0.00 & 0.00 & 0.01 & 0.00 & 0.00 & nd \\
\hline & $\mathrm{CR}$ & 0.00 & 0.00 & 0.01 & 0.01 & 0.01 & 0.02 \\
\hline
\end{tabular}

(Note: $n d:$ not detectable)

Soil sample :

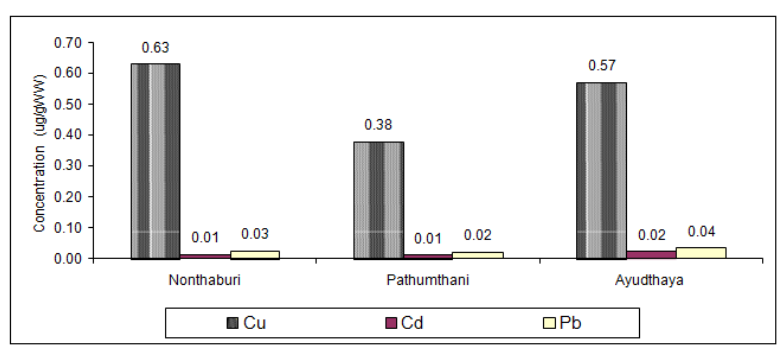

Fig. 3: Concentration of heavy metals in Morning Glory (Edible part)

Analysis results from soil samples in all three provinces showed that the $\mathrm{Cu}$ concentration accounted for the highest percentage among the remaining two metals. This $\mathrm{Cu}$ concentration was highest in Non- thaburi Province $(0.63 \mathrm{ug} / \mathrm{gWW})$, which was not statistically significant different from Ayutthaya province $(0.57 \mathrm{ug} / \mathrm{gWW})$ $(\mathrm{p}>0.05)$. However, this concentration was statistically significantly different from Pathum Thani province $(0.38 \mathrm{ug} / \mathrm{gWW})$ $(\mathrm{p}<0.05)$. Cd concentration in all three provinces ranged from $0.01-0.02$ ug $/ \mathrm{gWW}$, this concentration was not statistically significant different between provinces ( $\mathrm{p}>0.05)$, and the $\mathrm{Pb}$ concentration showed similar results. The results also show that the $\mathrm{Cu}$ concentration accounts for a high percentage, compared to the $\mathrm{Cd}$ and $\mathrm{Pb}$ concentration in the three provinces.

Figure 4 shows concentrations of heavy metals $(\mathrm{Cu}, \mathrm{Cd}, \mathrm{Pb})$ in the provinces. Cop- 
per and lead were higher compared to cadmium.

The research results from Figure 4 show that the $\mathrm{Cu}$ and $\mathrm{Pb}$ concentration in Nonthaburi Province is the highest among the three provinces, accounting for 20.26 $\mathrm{ug} / \mathrm{gWW}$ and $16.05 \mathrm{ug} / \mathrm{gWW}$, respectively. The Cd concentration in the three provinces accounted for a negligible rate ranging from 0.11 to $0.23 \mathrm{ug} / \mathrm{gWW} \mathrm{Cd}$ and $\mathrm{Pb}$ concentrations in Ayutthaya were highest, whereas their concentrations were the lowest in Nonthaburi.

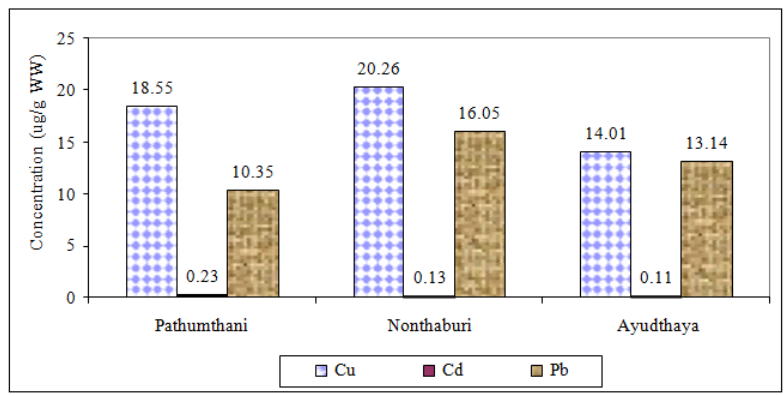

Fig. 4: Concentration of heavy metals in soil of Morning Glory in wet season

\section{Water of Morning glory}

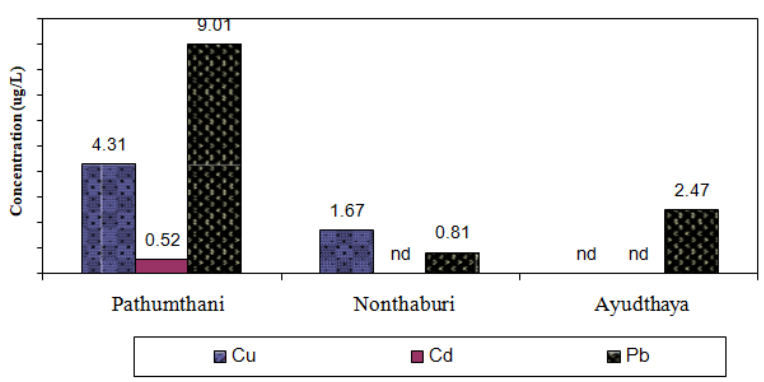

Fig. 5: Concentration of heavy metals in water samples of Morning Glory

The water samples collected from the morning glory farms were also analyzed by ICP-AES. Concentrations of $\mathrm{Pb}$ in water samples were found the highest in Pathum Thani $(9.01 \mu \mathrm{g} / \mathrm{L})$ and were the lowest in Nonthaburi $(0.81 \mu \mathrm{g} / \mathrm{L})$. Cd concentration was negligible in Nonthaburi and Ayutthaya, but a higher concentration was found in Pathum Thani $(0.52 \mu \mathrm{g} / \mathrm{L})$.

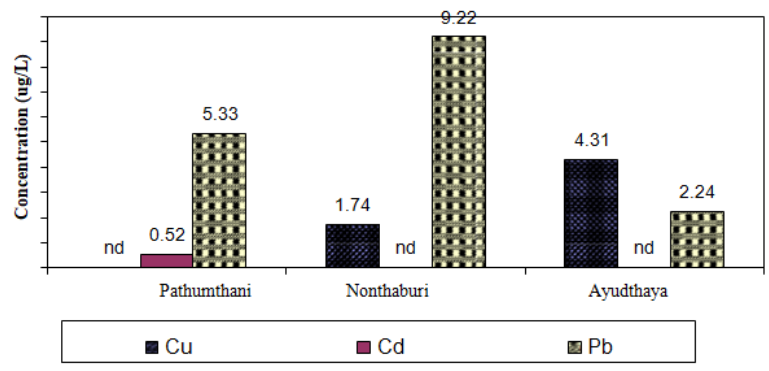

Fig. 6: Concentration of heavy metals in water samples of lettuce

Similarly, the concentration of $\mathrm{Pb}$ in the lettuce farm was the highest in Nonthaburi $(9.22 \mu \mathrm{g} / \mathrm{L})$, and was lowest in Ayutthaya $(2.24 \mu \mathrm{g} / \mathrm{L})$. From the results, Cd concentration was not found in Nonthaburi and Ayutthaya but it appeared in Pathum Thani in trace amounts $(0.52 \mu \mathrm{g} / \mathrm{L})$. Due to the unavailability of Chinese Radish in Ayutthaya and Pathum Thani, the results of the heavy metals concentration could not be compared among the three provinces.

\section{Dry Season - Farm}

Vegetable sample

Concentration of heavy metals (edible parts of Morning-glory) in Nonthaburi, Pathum Thani, and Ayutthaya is presented in Figure 7. The $\mathrm{Cu}$ concentration in Nonthaburi (1.48 ug/gWW) was highest and in Pathum Thani $(0.16 \mathrm{ug} / \mathrm{gWW})$ was the lowest. Likewise, $\mathrm{Cd}$ concentrations in all three provinces were similar $(0.01$ ug/g WW). The Pb concentrations in Non- 


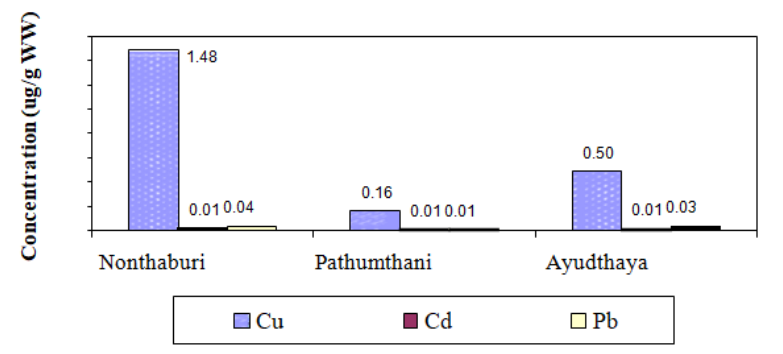

Fig. 7: Concentration of heavy metals in Morning Glory (Edible part) in dry season

thaburi and Ayutthaya were $0.04 \mathrm{ug} / \mathrm{gWW}$ and $0.03 \mathrm{ug} / \mathrm{gWW}$ respectively, while its concentrations in Pathum Thani were only $0.01 \mathrm{ug} / \mathrm{g} \mathrm{WW}$.

Soil sample

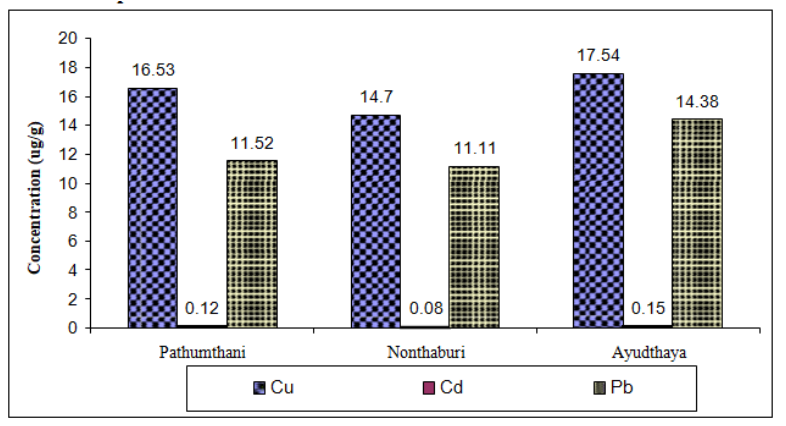

Fig. 8: Concentration of heavy metals in soil of morning glory

Figure 8 shows that the concentration of $\mathrm{Cu}$ in the morning glory soil samples the highest compared to that of $\mathrm{Pb}$ and $\mathrm{Cd}$, whereas the $\mathrm{Pb}$ concentrations in all three provinces were found similar about $11.11,11.52$ and $14.38 \mathrm{ug} / \mathrm{g} \mathrm{WW}$. But the concentrations of $\mathrm{Cd}$ were found lowest in comparison to lead and copper. It can be concluded that the concentrations of heavy metals in the soil were found higher than that in the vegetables grown in that soil - as the pathway of contamination of heavy metals in vegetables are through soil, and the heavy metals concentration in the soil were found to be not higher.

Concentration of heavy metals in edible parts of morning glory

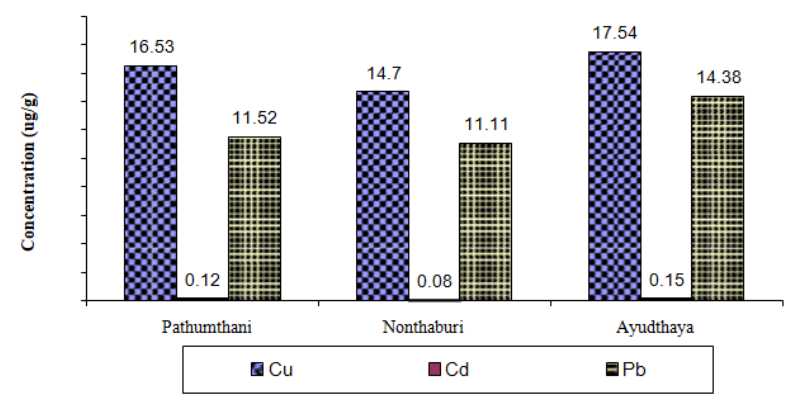

Fig. 9: Concentration of heavy metal in edible of MG in dry season in three provinces are Pathum Thani, Nonthaburi, and Ayutthaya

The research results from Figure 9 show that $\mathrm{Cd}$ concentration accounts for a relatively low percentage among the remaining two metals ranging from 0.08 $\mathrm{ug} / \mathrm{gWW}$ in Nonthaburi Province and 0.15 ug/g WW in Ayutthaya province. Meanwhile, $\mathrm{Cu}$ content accounts for the highest percentage compared to the other two metals, the highest being in Ayutthaya province, with a result of $17.54 \mathrm{ug} / \mathrm{g}$ WW. Concentrations of $\mathrm{Pb}$ measured in these three provinces also ranged from 11.11 to $14.38 \mathrm{ug} / \mathrm{gWW}$.

In summary, the concentration of $\mathrm{Cu}$ in morning glory in the dry season is higher than the other two concentrations because during this season the amount of water limited, so vegetables absorbed more nutrients from the soil resulting in a higher $\mathrm{Cu}$ result. 
Concentration of heavy metals in edible parts of Chinese radish

The $\mathrm{Cu}$ concentrations in edible parts of the Chinese radish samples in the dry season were found higher in both the market and supermarkets, except Big $\mathrm{C}$ and Thala Thai were higher than that in Simu Muong, and $\mathrm{Cd}$ and $\mathrm{Pb}$ concentrations were negligible except in Big C QL and Big C.

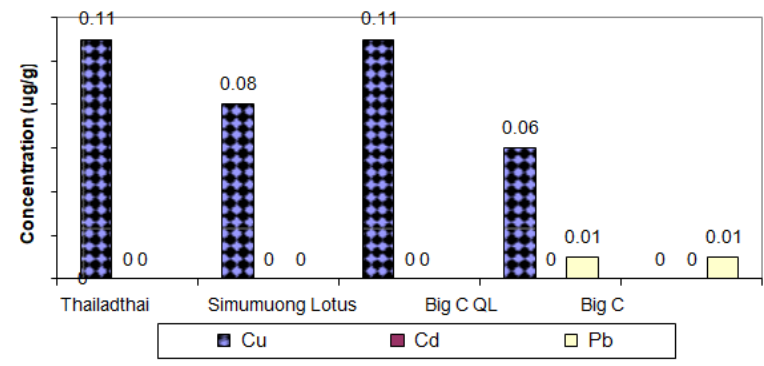

Fig. 10: Concentration of heavy metal in edible parts of Chinese radish in dry season in markets and supermarkets

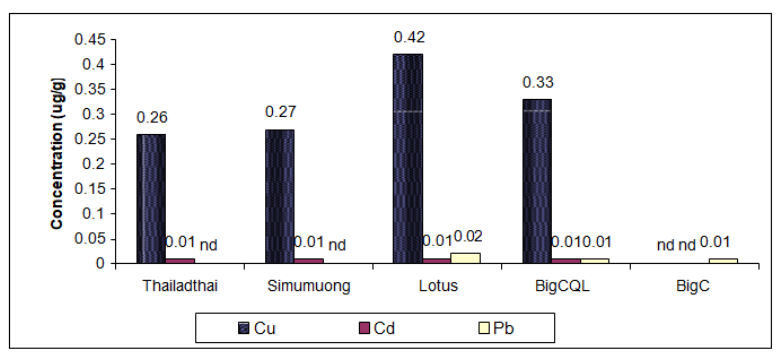

Fig. 11: Concentration of heavy metals in edible of lettuce in dry season in markets and supermarkets

Heavy metal concentration results in the markets were found to be similar, whereas they were different in the supermarkets. The $\mathrm{Cu}$ concentration in the Lotus super- market was the highest compared to other supermarkets, and the concentration was negligible in Big C. Similarly, Cd concentrations in all markets and supermarkets were found $0.01 \mathrm{ug} / \mathrm{gWW}$. But $\mathrm{Cd}$ and $\mathrm{Cu}$ concentrations in Lettuce were not found in both markets and supermarkets as shown in Figure 11.

Concentration of heavy metal in nonedible parts of Chinese radish

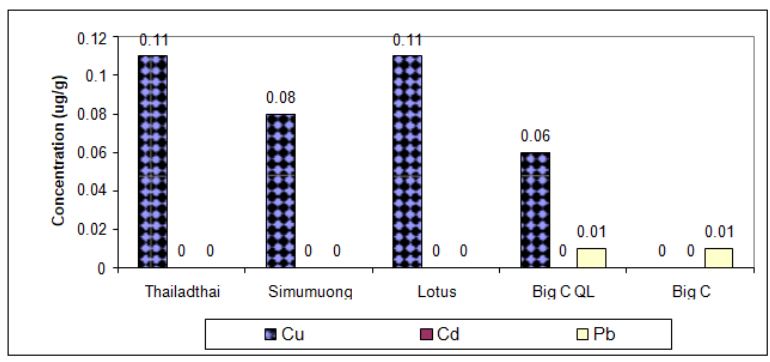

Fig. 12: Concentration of heavy metal in non-edible parts of Chinese radish in dry season

Figure 12 highlights the concentration of $\mathrm{Cu}$ in Thailadthai and Lotus is equal at $11 \mathrm{ug} / \mathrm{g}$, which is the highest compared to Simumuong and $\mathrm{Big} \mathrm{C}$, the $\mathrm{Pb}$ that was found in Big C QL and Big C was 0.01 $\mathrm{ug} / \mathrm{g}$.

Interestingly in Big C QL and Big C, Cu is not found, and $\mathrm{Cd}$ was not found in all five sites.

\section{CONCLUSION}

In this experiment heavy metal concentrations were analyzed and the following conclusions can be made: the concentrations in the vegetables were found to be lower than that of soil, water, manure and fertilizer. 
However, analysis of more samples should be done, and the information obtained used for setting a standard concentration limit in vegetables. Identification of the possible sources of toxic metals in manure should also to promote the usage of manure. Farmers should be motivated to utilize organic manure over chemical fertilizer. A mass balance should be conducted in order to understand the total heavy metal input and output from the soil, as well as the accumulation in the soil in the GBR.

\section{ACKNOWLEDGEMENT}

I would like to express my profound gratitude to my advisor, Dr. Preeda Parkpian for her kind guidance, constructive comments, support, and encouragement throughout my research work. Special thanks is extended to the committee members, Prof. Chongrak Polprrasert, Dr. Thamarat Koottatep and all Doctoral assistants in the Environment Engineering and Management team for their guidance.

\section{TÀI LIỆU THAM KHẢO}

[1] Dong Thuy. Rau ban Hien trang hien nay o Viet Nam. 2018. Available from: http://organicshop-agenas.com/rau-banthuc-trang-hien-nay-o-viet-nam/ [Accessed 30th March 2021].

[2] S.B. Agrawal, Anita Singh, R.K. Sharma. M. Agrawal. Bioccumulaton of Heavy Metals in Vegetables: A threat to Human Health. Terrestrial and Aquatic Environmental Toxicology. Global Science Books. 2007.
[3] Paul B Tchounwou, Clement G Yedjou, Anita K Patlolla, Dwayne J Sutton. Heavy Metals Toxicity and the Environment. HHS Public Access. 2012; 101:133-164.

[4] Iwona Morkuna, Agnieszka Wozniak, Van Chung Mai, Renata Rucinska-Sobkowiak and Philippe Jeandet. The role of heavy metals in plant response to Biotic stress. Molecules. Article in PMC. 2018

[5] Luu Anh. The harm of arsenic and cadmium. 2017. Available from: https://suckhoenamviet.com/cadmium-conmot-an-mon-xuong-cua-ban). [Accessed 30th Ausgust 2020].

[6] Md. Shakil Ahmed, Md. Mahfuzul Hasan Biswa, Md. Abdul mottalib, Myhammad Nur Alan, Mala Khan. Translocation of heavy metals from industry into vegetables andcrops through water and soil of Mokesh Beel in Bangladesh and their impact on human body. Journal of Environmental Science, Toxicology and Food Technology. 2019; 13(5):2319-2402.

[7] Hoang Trung. Heavy metal poisoning affects health. 2010. Available from: https://anninhthudo.vn/nhiem-doc-kimloai-nang-nguy-co-tiem-an-voi-suc-khoepost66859.antd. [Accessed 30th Ausgust 2020].

[8] Le Thanh Tam, Nguyen Minh Khang. Assessment of heavy metal content in agricultural products in Ho Chi Minh City and survey of metal attraction of broccoli [Graduation thesis]. Ho Chi Minh City University of Agriculture and Forestry. 2011.

[9] Nguyen Ngan Ha, Nguyen Minh Phuong, Nguyen Mai Anh. Assessment of heavy 
metal, nitrate content in soil and vegetables in some vegetable growing areas in Soc Son district. Science magazine, Hanoi National University. 2016; 32;118-124.

[10] Pham Ngoc Thuy, Nguyen Dinh Manh, Dinh Van Hung, Nguyen Viet Tung, Ngo Xuan Manh et al. Current status of heavy metals (Mercury, Arsenic, Lead and $\mathrm{Cd}$ ) in the country and some vegetables grown in Dong Anh district, Hanoi. Vietnam Journal of Agricultural Sciences- VJAS. 2006; 4-5. Available from: http://tapchi.vnua.edu.vn/so-4-va5-nam-2006/ [Accessed 3rd September 2020].

[11] Duong Thi Huyen. Analyzing and evaluating the concentration of heavy types of $\mathrm{Cd}$, $\mathrm{Cu}, \mathrm{Pb}$ in Ngai Cuu plants [Master thesis]. Thai Nguyen University. 2018. 